\title{
Household Debt and Social Interactions
}

\author{
Dimitris Georgarakos \\ Goethe University Frankfurt, CFS and University of Leicester
}

Michael Haliassos
Goethe University Frankfurt, CFS and CEPR

Giacomo Pasini

Ca' Foscari University of Venice and NETSPAR

\begin{abstract}
Can concern with relative standing, which has been shown to influence consumption and labor supply, also increase borrowing and the likelihood of financial distress? We find that perceived peer income contributes to debt and the likelihood of financial distress among those who consider themselves poorer than their peers. We use unique responses describing perceived peer characteristics from a Dutch population-wide survey to handle two major challenges of uncovering social interaction effects on borrowing: (1) debts, unlike conspicuous consumption, are often hidden from peers and (2) location is missing in anonymized data. We employ several approaches to uncover exogenous, rather than correlated, effects. (JEL G11, E21)
\end{abstract}

The role of relative standing has been explored in many contexts, including consumption behavior and labor supply, ${ }^{1}$ but less attention has been paid to how "catching up" or "keeping up" with peers is financed. In particular, almost no attention has been paid to whether perceptions of relative standing contribute to borrowing and to the potential for financial distress. Are people who perceive themselves as poorer than their social circle more likely to borrow and, if

\footnotetext{
We are grateful to an anonymous referee and Alexander Ljungqvist (editor) for their very helpful comments. We would also like to thank Rob Alessie, Bas Donkers, Steven Durlauf, Jordi Gali, John Gathergood, Luigi Guiso, Yannis Ioannides, Mauro Mastrogiacomo, Luigi Pistaferri, Nikolai Roussanov, Dorothea Schäfer, Jan Sokolowsky, Kostas Tatsiramos, and seminar participants at the Sloan Conference on Household Behaviour in Mortgage and Housing Markets, Saïd Business School, Oxford, European Economic Association Annual Congress in Malaga, CeRP Conference on Financial Literacy, Saving and Retirement in an Ageing Society, Turin, NETSPAR International Pension Workshop, Amsterdam; Behavioral Finance Conference, DIW, Berlin, 10th Conference on Economic Theory and Econometrics (CRETE), Greece, Association of Southern European Economic Theory (ASSET) conference in Evora, Portugal, DFG Conference in Cologne, GSEFM conference in Mainz, IAES Conference in Istanbul, Universities of Bath, Freiburg, Southampton, Vienna and Rotterdam, CPB in Den Haag, HFC Network at the European Central Bank, and at the research department of Deutsche Bundesbank. M. H. acknowledges research funding from the German Research Foundation (DFG). Send correspondence to Dimitris Georgarakos, House of Finance, Grueneburgplatz 1, 60323 Frankfurt am Main, Germany; telephone: +49-69-798-34011. E-mail: georgarakos@hof.uni-frankfurt.de.

1 For instance, models with interdependent preferences have been applied to consumption (Abel 1990; Gali 1994), asset pricing (Campbell and Cochrane 1999), supply of labor (Neumark and Postlewaite 1998), work efforts (Cohn et al. 2011), and investing in assets (Duflo and Saez 2002; Kaustia and Knüpfer 2012).
}

(C) The Author 2014. Published by Oxford University Press on behalf of The Society for Financial Studies. All rights reserved. For Permissions, please e-mail: journals.permissions@oup.com. doi:10.1093/rfs/hhu014 
so, to borrow more relative to what is typically associated with their own resources and characteristics? Does such socially induced borrowing contribute to a worsening of indicators of potential financial distress, such as the debtto-income and loan-to-value ratios? This study uses unique, population-wide survey data and a battery of statistical approaches to examine the role of such social effects on borrowing.

Investigating the influence of social interactions on debt behavior presents at least two major challenges. First, many households are willing to display their assets and consumption but prefer to leave any debts undisclosed. Thus, it makes sense to look for evidence that households adjust their debt behavior not to the debts of their peers per se but to their perception of relevant peer characteristics. In the Manski (1993) terminology, instead of "endogenous effects", one needs to focus on "exogenous (or contextual) effects."

A second challenge has to do with the scarcity of location information. In view of privacy laws dictating anonymity of information, data collectors typically remove location details, but this step makes it impossible to identify a circle of "neighbors" or "colleagues" at work. Existing studies that examine social influences on consumption or assets typically define a social circle based on sample units with a common set of characteristics (e.g., age and education). A number of researchers have focused instead on a special population group and a financial asset class observed by peers, whereas others have examined sociability as a factor facilitating the collection of asset-relevant information. ${ }^{2}$

To the best of our knowledge, this paper is the first to investigate the influence of social interactions and comparison effects on borrowing behavior. Our study focuses on peer income, rather than peer debts, which are typically unobservable, and exploits a unique feature of our data, namely, that the respondents report various characteristics of their (unnamed) peers as these respondents actually perceive them.

We use data from the Dutch National Bank Household Survey (DNBHS), which is representative of the entire Dutch-speaking population, and we examine the role of perceived relative standing for collateralized loans and consumer (uncollateralized) loans. We find that once we control for demographics, resources, region, time fixed effects, region-specific time trends, and other factors that typically determine borrowing needs, a higher average income in the social circle, as perceived by a household, increases a household's tendency to borrow. ${ }^{3}$ Not only is this influence significant among those who perceive their income to be below average for their social circle, it also extends

2 See, for example, the seminal papers by Duflo and Saez (2002), focusing on librarians and a specific retirement product, and by Hong, Kubik, and Stein (2004), focusing on sociability.

3 The estimated effects are sizeable for both collateralized and consumer debt: a 1,000 euro increase in the perceived monthly average household income of peers (corresponding to 0.85 of one standard deviation of peer income) is estimated to raise the unconditional likelihood of having collateralized (uncollateralized) loans by $10 \%$ (7\%). 
to the likelihood of future financial distress, indicated by the debt service ratio and the loan-to-value ratio.

We verify the robustness of these results using several approaches, including instrumental variable estimation and placebo tests. Our aim is to rule out uninteresting alternative explanations of the peer-income-own-borrowing relation and address the potential for reverse causality or spurious correlation between the two, because of similarities in unobserved characteristics with those of peers.

We stress that the research question of social influences on debt is distinct from that relating to consumption; concern with relative standing may lead to greater consumption, but it need not lead to a greater tendency to borrow or to run into financial distress for at least three reasons. First, households can increase labor supply, leaving room for an increase in both consumption and saving. For example, Neumark and Postlewaite (1998) find that married women in the United States are $16 \%$ to $25 \%$ more likely to work outside the home if their sisters' husbands earn more than their own. Even a positive labor supply response can imply either more or less saving/borrowing. ${ }^{4}$ Second, households may choose to reduce saving but may not be willing or able to raise borrowing in response to status concerns. Third, even if borrowing is undertaken to keep up with peers, it may not significantly increase the potential for financial distress.

Our paper offers clues as to how comparison-motivated consumption is financed and provides the debt counterpart to analyses of the socially induced asset choices of households. Duflo and Saez (2002) demonstrate that individual participation in retirement investment plans is influenced by colleagues' participation choices. Hong, Kubik, and Stein (2004) show that more sociable individuals are more likely to own stocks. ${ }^{5}$ In both cases, the likely mechanism is one of emulating peers' asset choices once these are observed, a channel much less likely to be relevant for unobserved debts.

The importance of peer income for consumption was first formalized in Duesenberry's (1949) relative income hypothesis. According to this hypothesis, households with incomes below average in their social circle tend to consume a larger share of their income to keep up with peers. Recent work by Kuhn et al. (2011) finds that exogenous variations in income from winning a Dutch postal lottery tend to influence not only the durables purchased by winners but also the probability that neighbors will buy a new car. The financing of the neighbors' induced spending is not explored.

Charles, Hurst, and Roussanov (2009) show that the desire to signal status can explain why minority races in the United States tend to spend larger

4 Most existing theoretical models, which are based on an infinite-horizon representative agent, imply greater consumption, less leisure, and greater accumulation of assets to keep up with the Joneses, both now and in the future (Liu and Turnovsky 2005). When Alvarez-Cuadrado and Van Long (2008) consider overlapping generations in an infinite-horizon economy, however, they find less leisure but also less saving.

5 See also Brown et al. (2008) and Georgarakos and Pasini (2011). 
fractions of their budgets on conspicuous consumption than do whites with similar permanent incomes. Such outlays are financed through lower minority spending on other items (particularly health and education) and through savings, although the extant research does not investigate borrowing. ${ }^{6}$

This paper is organized as follows. Section 1 describes the unique features of our data set. Section 2 discusses possible channels through which peers might influence borrowing behavior and the econometric approach taken to address a number of challenges. Section 3 presents the baseline results on the relation between peers' income and debt behavior, whereas Section 4 reports the results of the placebo tests and additional robustness checks. Section 5 shows the asymmetric effects on borrowing across households poorer and richer than the peer average and inspects likely channels through which peer income operates. Section 6 concludes the paper.

\section{The Data}

The DNBHS, launched in 1993, provides a unique data set that includes information on work, pensions, housing, mortgages, incomes, assets, consumer loans, health, economic, and psychological concepts, and personal characteristics. Thus, it allows the study of both the psychological and economic aspects of financial behavior. The initial survey was administered to roughly 2,790 Dutch households oversampled from the top $10 \%$ of the income distribution and weighted to be representative of the Dutch-speaking population. Since then, households have been reinterviewed annually, with new households added each year to counteract nonnegligible attrition and keep the cross-sectional sample representative. Because the survey underwent major refreshing in 2001, resulting in a sample of 1,861 households, we pool data from the 2001 to 2008 waves, which cover a period of relatively stable employment rates and increasing housing prices. $^{7}$ After excluding households with incomplete questionnaires or missing information on social circle characteristics, the sample used in the baseline estimations consists of approximately 4,500 households.

This survey not only includes an extensive questionnaire on income and real and financial wealth holdings but also asks specific debt-related questions. These responses allow us to distinguish between two types of formal borrowing: collateralized and uncollateralized loans. ${ }^{8}$ Table 1 provides summary statistics

6 A link between conspicuous consumption and borrowing is addressed, however, in the theoretical model of status developed by Rayo and Becker (2006), who argue that, to signal status to more people over a longer period of time, conspicuous consumption goods tend to be durable, which often requires borrowing finance.

7 Unemployment rates in the Netherlands reached a minimum of 3\% in 2008 but increased to $3.7 \%$ and $4.5 \%$ in 2009 and 2010, respectively. National housing prices increased, on average, by roughly $2 \%$ each year until 2008 , after which they declined by $2.8 \%$ in 2009 and by $3.4 \%$ in 2010 .

8 The survey also collects information on informal loans from family and friends, which show relatively low prevalence $(4 \%)$. 
Table 1

Prevalence and amount of borrowing by loan type

Panel A: Collateralized loans

\begin{tabular}{|c|c|c|c|c|c|}
\hline & \multirow[b]{2}{*}{ Prevalence $(\%)$} & \multicolumn{4}{|c|}{ Conditional amounts outstanding } \\
\hline & & Average & 25 th perc & Median & 75 th perc \\
\hline 2001 & $37.81 \%$ & 105,038 & 44,857 & 83,118 & 131,934 \\
\hline 2002 & $43.22 \%$ & 113,177 & 45,760 & 89,288 & 139,512 \\
\hline 2003 & $43.12 \%$ & 113,921 & 44,298 & 90,757 & 146,940 \\
\hline 2004 & $40.96 \%$ & 110,673 & 46,562 & 92,065 & 145,405 \\
\hline 2005 & $41.25 \%$ & 118,971 & 51,238 & 100,384 & 156,851 \\
\hline 2006 & $40.69 \%$ & 117,246 & 49,353 & 100,763 & 159,370 \\
\hline 2007 & $41.02 \%$ & 132,048 & 59,944 & 111,760 & 181,864 \\
\hline 2008 & $40.92 \%$ & 132,920 & 61,750 & 120,000 & 180,000 \\
\hline Total & $41.15 \%$ & 117,926 & 48,620 & 98,293 & 156,664 \\
\hline \multicolumn{6}{|c|}{ Panel B: Consumer loans } \\
\hline & & \multicolumn{4}{|c|}{ Conditional amounts outstanding } \\
\hline & Prevalence $(\%)$ & Average & 25 th perc & Median & 75 th perc \\
\hline 2001 & $22.24 \%$ & 11,451 & 956 & 4,486 & 11,610 \\
\hline 2002 & $24.62 \%$ & 9,448 & 843 & 4,659 & 12,344 \\
\hline 2003 & $25.86 \%$ & 13,030 & 918 & 4,415 & 13,487 \\
\hline 2004 & $25.09 \%$ & 11,315 & 835 & 4,021 & 11,794 \\
\hline 2005 & $19.13 \%$ & 14,957 & 1,045 & 4,273 & 12,548 \\
\hline 2006 & $18.64 \%$ & 11,267 & 853 & 4,138 & 12,287 \\
\hline 2007 & $20.57 \%$ & 11,196 & 889 & 3,835 & 11,379 \\
\hline 2008 & $20.33 \%$ & 12,008 & 680 & 3,750 & 11,206 \\
\hline Total & $22.09 \%$ & 11,793 & 875 & 4,181 & 12,155 \\
\hline
\end{tabular}

Weighted statistics from waves 2001-2008 of DNBHS data. Amounts refer to constant 2008 euro.

on the prevalence and outstanding amounts among debt holders by survey year and by loan type. These figures suggest a relatively stable prevalence of both types of loans over the years studied. Collateralized debts account for most household borrowing, being held by approximately $40 \%$ of the households, with a median conditional outstanding amount of approximately 98,000 euro. One out of five Dutch households has consumer loans, with a median outstanding amount of approximately 4,000 euro. ${ }^{9}$

In the absence of information on respondents' perceptions of peers, the empirical network literature typically constructs hypothesized social circles based on sorting assumptions (e.g., age-education cells or geographic proximity). One unique feature of the Dutch survey most relevant for our purposes here is that individuals are asked to explicitly report a number of characteristics about those with whom they "associate frequently, such as friends, neighbors, acquaintances, or maybe people at work." This subjective information can be particularly helpful for understanding who interacts with whom and circumvents the key issue of defining the social circle. Indeed, Soetevent (2006) stresses the potential of such questions for social interaction

9 Extended lines of credit (unrelated to home equity) account for roughly $40 \%$ of the average outstanding volume of consumer loans, followed by almost $20 \%$ from checking account overdrafts. Student loans account for $17 \%$, and private loans account for $12 \%$. Only $6 \%$ relate to outstanding credit card debts. 
models, whereas Woittiez and Kapteyn (1998) exploit such subjective information from the DNBHS to assess peer effects on the female labor supply. Being specific, respondents report their perceptions of the average annual total net household income among people in their social circle, which is recorded in one of eleven income brackets (see Appendix A). Other questions cover the age category of most members of their social circle, as well as the average household size, average education, most prevalent type of employment, and average hours of work per week of their peers distinguished by gender. The survey also asks directly about respondents' interactions with peers in relation to exchanging financial information or informal borrowing, perceptions of the social circle's spending ability, and expectations about their own future income. We use this information in the empirical analysis to shed light on the process through which social interactions influence borrowing behavior.

\section{Effects of the Social Circle on Debt Behavior}

\subsection{Possible channels}

The asset market participation and holdings of peers may influence a member of the peer group via direct observation of financial behavior, information sharing, and dissemination of social norms. However, peer effects in borrowing behavior are much less likely to emanate from direct observation of peers' loans or even from discussions with them about their indebtedness. That is, loans, unlike assets, are not directly observable by third parties and can only become known if borrowers decide to reveal them, but borrowers are less likely to discuss their loans than exhibit their assets because of embarrassment or shame. ${ }^{10}$ Nonetheless, financial advice and consultation with members of the social circle may inform households about the process of obtaining loans and/or about the social norms of borrowing. We can explicitly take this possible channel of effects into account because our data allow us to identify households that consult family, friends, and acquaintances about financial decisions and that can borrow from their social circle in the future.

Even households that do not consult their social circle may still be influenced by that circle's observable behavior when deciding whether to take out a loan and how much to borrow. Households form perceptions about acquaintances' average disposable income based on sources of social interaction ranging from direct knowledge of acquaintances' pay scales to open discussions with friends and family and inferences about income levels from observed spending or asset accumulation patterns. Because the DNBHS asks respondents directly about the perceived average income of their acquaintances, we can directly assess the influence of these perceptions on their borrowing behavior. In doing so, we assume that perceptions of higher peer income may contribute positively

10 Collins et al. (2009) find that even in developing countries with weak credit markets many indebted households feel ashamed to ask relatives for additional credit in order to not reveal their financial situation. 
to borrowing through three possible channels: trying to emulate the spending or living standards of acquaintances (a comparison effect), inferring that more can be borrowed directly from them in the future, and inferring that one's own future income is likely to move in the same direction as that of one's social circle (an expectation or "tunnel effect" in the terminology of Hirschman and Rothschild 1973). ${ }^{11}$

With reference to the first channel, a spending behavior or visible accumulation of assets (like housing) by members of a social circle may well induce a household to borrow to match (or exceed) it. Our data allow us to observe respondents' perceptions of peers' spending ability and to take them into account in our estimation for consumer debt (unfortunately, we cannot gain similar insights for collateralized debt, given that we do not observe respondents' perceptions of peers' housing or living standards). The data do allow us to directly address the second channel, using household responses on whether they are in a position to borrow a significant amount of money from friends and relatives. In regard to the third channel, we first use households' reported expectations about their own future income and then examine the robustness of our results using a measure of respondents' permanent incomes rather than expected future incomes.

\subsection{Econometric specification}

Our aim is to examine whether households' own borrowing decisions are influenced by the (perceived) average income of their peers. Following the notation of Moffitt (2001), suppose that there are $g=1, \ldots, G$ peer groups and $i=1, \ldots N_{g}$ households in each group. In our baseline specification, we estimate equations of the following type:

$$
y_{i g}=\beta_{x} x_{i g}+\gamma_{x} x_{g}+Z_{1, i g}^{\prime} \beta+Z_{2, g}^{\prime} \gamma+\varepsilon_{i g},
$$

where $y_{i g}$ denotes either a binary ownership indicator or the outstanding amount of a particular loan type; $x_{i g}$ is the household's own income; and $x_{g}$ is the perceived average income of the household's peers. $Z_{1, i g}$ and $Z_{2, g}$ represent two vectors with additional household and peer group characteristics, respectively. ${ }^{12} \varepsilon_{i g}$ denotes the error term. Households are asked directly to provide an estimate of the income of their peers: "If you think of your circle of acquaintances, how much do you think is the average total net income per year

11 Hirschmann and Rothschild stress utility-enhancing "anticipatory feelings" (Caplin and Leahy 2001), analogous to those felt by an individual who, caught in a traffic jam in a tunnel, sees another lane moving and anticipates that her own line will also move soon. Senik (2004) finds empirical support for the "tunnel effect" using survey data from Russia.

12 Household own characteristics include age, gender, educational attainment, marital status, number of children, self-reported health, labor status, whether last year's income was unexpectedly low, whether the household expects to borrow from peers in the future, whether it gets financial advice from peers, and net financial and real wealth. Peer group characteristics consist of average education of peers (in baseline specifications), as well as peer average age, household size, and employment status in robustness specifications (presented in Section 4). 
of those households?" The possible answers are presented in brackets. In our reported results, we use the midpoints of these bands, adjusted for inflation. In the Appendix, we detail a number of robustness checks that employ different specifications of this variable. ${ }^{13}$ In terms of Equation (1), given that each household provides a direct average estimate of its own peers' characteristics, the peer sample size for each household is one. Importantly, using such a directly elicited measure circumvents the issue of identifying the characteristics of the peers with which each household actually interacts.

The extant literature on social interactions in consumption or asset investing focuses on uncovering what Manski (1993) calls "endogenous social effects", namely, the direct effects of observing others' behavior (e.g., consumption or asset holdings) on one's own actions. ${ }^{14}$ Econometric modeling in this context must address the reflection problem generated when the behavior of households in a group is expressed as a function of the average behavior of the group that includes them (i.e., adding $y_{g}$ on the right-hand side of Equation 1). Given that debts, as discussed earlier, are typically unobservable by other social circle members, our primary focus is on uncovering exogenous or contextual effects ( $\gamma_{x}$ in our model), that is, influences on debt behavior that emanate from observing (or forming perceptions of) average peer income, $x_{g} \cdot{ }^{15}$ In this setting, the two major challenges are to rule out (1) spurious links between peer income and the respondent's own borrowing behavior that have little to do with a comparison effect and (2) correlated effects, an association between these two variables stemming from similarities in the unobserved characteristics of the respondent or respondent's environment and those of peers.

One standard, albeit uninteresting, potential source of an effect of peers' higher perceived income on borrowing relates to an adverse idiosyncratic shock; that is, once income is controlled for, the higher the perceived average income of peers is, the greater the chance is that the household has experienced a bad idiosyncratic shock during this period. In such a case, standard models would prescribe more borrowing to smooth any adverse transitory shock. We control for this possibility by including self-reported health, labor market status dummies, and, most especially, answers to a direct question on whether last year's income was "unusually low" in our specifications. In addition, as described in Section 4, we estimate models that control for a household's permanent income proxy that is more resilient to temporary shocks.

13 We experiment, for example, with using dummy variables for income bands and a flag dummy for "don't know" responses, but the results are insensitive to these variations.

14 For thorough reviews of methodological issues in social interaction models, see Soetevent (2006) and Durlauf and Ioannides (2010).

15 Note that in a probit model for the likelihood of having a loan, the reflection problem cannot occur, given that the expected outcome is a nonlinear function of the individual level variables, except for nongeneric cases for the density of model errors, e.g., uniform density (Brock and Durlauf 2001a, 2007). In addition, the reflection problem does not occur when we use linear models to estimate Equation (1) as long as there are elements in $Z_{1, i g}$ whose averages do not appear in $Z_{2, g}$ (see Brock and Durlauf 2001b, their Theorem 6; Blume et al. 2011, their Theorem 1). 
Another possibility is that the respondent's perception of higher income in the social circle partly reflects a macro or regional shock, such that perceptions could improve simply based on better performance in the macroeconomy or the region in which most of the social circle is located. We take these two channels into account flexibly by including both year and province fixed effects in all our specifications. To account for any region-specific time trends that may correlate with trends in both peer income and borrowing (e.g., more rapid housing price appreciation in certain regions), we condition our specifications on a full set of interaction terms between province and year fixed effects. ${ }^{16}$

A more complex potential channel for an association between peer income and borrowing is correlated effects; that is, there may be unobserved factors that influence both the desire to borrow and the desire to associate with certain groups of peers. The presence of such unobserved factors will render standard estimates of $\gamma_{x}$ inconsistent, whereas the direction of the induced bias will be unknown (for more details, see Appendix C).

We also consider the possibility of reverse causality; households may borrow with the specific aim of associating with people whom they perceive as earning more, or households may come to think of their peers as having more income because they borrow. Therefore, we consider both possibilities: correlated effects and reverse causality.

One possible approach to addressing the former would be to allow for peer group fixed effects; however, because this method cannot also handle potential reverse causality, it is not the most suitable choice for our data. Moreover, this method's application would require that the peer groups be either known or assumed and that the (observable) variation within them be sufficient to identify the causal relation of interest. ${ }^{17}$ A key advantage of our data is that they allow us to avoid making arbitrary assumptions about the identity of peers or respondents' perceptions of peers because they ask respondents directly about their perceptions of peer characteristics. However, our data record perceptions regarding the average characteristics of peersnot variation within a given peer group. Thus, applying this method would be inconsistent with exploiting the strengths of our data. Rather, we pursue two alternative ways to address identification in the presence of correlated effects: instrumental variable estimation, which also addresses concerns of possible reverse causality, and estimation of peer income's influence using a series of placebo regressions.

With reference to the instrumental variable estimation, our identification strategy exploits variations in local labor market conditions and the asymmetric

16 When modeling collateralized borrowing, we also conduct a series of robustness checks to examine the sensitivity of our results to the inclusion of certain relevant regional indicators and to a specific functional form of time trends (i.e., instead of the general form adopted in the baseline regressions).

17 See, for example, Lundborg (2006) and Soetevent and Kooreman (2007), who use school-grade (or class) fixed effects and exploit the variation within classmates to assess health behavior among adolescents in schools. 
effects that these can have for the incomes of households with different educational backgrounds. That is, a given difference in educational attainment between respondent and peers can imply a larger difference in (perceived) incomes in regions with better conditions for highly educated workers. For example, unanticipated positive shocks to earnings of workers in high-tech sectors could induce their less educated peers working in other sectors to borrow more in order to keep up. Note that, in the data, we do not observe the sector in which respondents and their peers work. Thus, we use the interaction between regional employment rates in high-tech sectors and the difference in educational attainment between each respondent and his peers as an instrument. At the same time, we control for the respondent's own educational attainment and occupational status, for peers' average level of educational attainment, for province and time fixed effects, and for the entire set of interactions between province and time fixed effects. ${ }^{18}$

Finding appropriate instruments is usually a difficult task and in what follows we discuss assumptions that can support our choice. First, the validity of the instrument rests upon the assumption that it is relevant. That is, the educational gap between a respondent and peers must raise the respondent's perception of peers' average income and even more so when the regional employment share in high-technology occupations, for which education matters greatly, is larger. ${ }^{19}$ Indeed, results from the auxiliary regression (presented in Table 2C) support this assumption, as they suggest a strong positive association between our instrument and the perceived income of peers (with an F-statistic well above the rule of thumb threshold of ten).

In addition, it is assumed that the instrument is exogenous (i.e., its effect on an individual's own borrowing runs through perceived peer income, but not other factors). Note that our model takes into account various determinants of borrowing, including own education, the education of peers, own income and idiosyncratic income shocks, as well as province and time fixed effects. ${ }^{20}$ One potential concern is that, if workers who do not work in high-tech sectors are in fact complementary to growth in these high-tech industries, then they are likely to move closer to these industries. This could possibly affect house prices in

18 "High-tech sector" refers to both high-tech manufacturing industries (the manufacturers of basic pharmaceutical products and pharmaceutical preparation computer, electronic, and optical products) and high-tech knowledgeintensive services (motion picture, video, and television program production, sound recording and music publishing activities, programming and broadcasting activities, telecommunications, computer programming, consultancy and related activities, information service activities, scientific research and development).

19 Virtually all heads of households in the sample have completed full-time education and were not attending any (full- or part-time) education program at the time of the interview. Hence, it is quite unlikely that relatively less-educated individuals living in regions with a high fraction of high-tech sector jobs would decide to borrow to invest in their human capital and thereby improve their career prospects.

20 Province fixed effects serve to absorb any regional disparities (e.g., due to development, unemployment, or bank diffusion) that are likely to have a direct influence on individual borrowing. Time fixed effects absorb any common time trend, whereas their interactions with provinces take into account any region-specific time trend. Peers' average level of education takes into account the educational attainment of peers that can be relevant for finding jobs in the high-tech sector (i.e., college or postsecondary education). 
the area and anticipated wage growth, both of which could contribute to greater borrowing. Although we cannot explicitly rule out this possibility, as we show below, our key findings remain unaffected when we control for yearly growth in housing prices by province and for expectations regarding future own income.

In light of the above, we assume that, conditional on the rich set of controls in our model, regional variation in employment rates in high-tech industry interacted with the educational gap between the respondent and peers, does not affect the tendency to borrow and the size of loan directly but through its correlation with the respondent's perception of average peer income. In the section to follow, we first present our baseline results and our results from endogeneity tests and instrumental variable models. In Section 4, we provide details and present results from our second identification strategy, which relies on placebo regressions.

\section{Results for the Role of Peer Income in Borrowing Behavior}

In this section, we report the results from our baseline specification for collateralized and consumer (uncollateralized) loans. We use Equation (1) to estimate prevalence and (conditional) amounts outstanding for each loan type by means of both linear (ordinary least squares [OLS]) and nonlinear models (i.e., probit for prevalence and Tobit for amounts outstanding). For each of these models, we also test for the possible endogeneity of the income of peers based on a Hausman test that is robust to heteroscedasticity. ${ }^{21}$ Under the null of no endogeneity, the estimates from the baseline model are consistent and more efficient and should be preferred to those derived from IVs. For completeness, we report the results from both the baseline estimates and their IV counterparts in all cases. Moreover, to make economic sense of our findings, we compute and show the average marginal effects for all models (along with their standard errors clustered at the household level).

Table 2A presents the results for collateralized loans. We estimate a statistically significant effect of the perceived average household income of the social circle (based on an assumed 12,000 euro annual increase), both on the likelihood of having a collateralized loan and on the (conditional) outstanding amount. $^{22}$ The estimated marginal effects from the OLS and probit are $4 \mathrm{pp}$,

21 The test is implemented as the difference of two Sargan-Hansen statistics, one calculated for the baseline equation, where income of peers is treated as endogenous, and the other for the baseline equation augmented by the instrument in which income of peers is treated as exogenous. Under the null hypothesis that the income of peers can actually be treated as exogenous, this C-statistic is distributed as chi-squared with one degree of freedom. We have also tested for endogeneity of the linear models using a Durbin-Wu-Hausman specification test and of the nonlinear models using the two-step procedure of Rivers and Vuong (1988). Results from these alternative tests are entirely consistent with those reported in Tables $2 \mathrm{~A}$ and $2 \mathrm{~B}$.

22 Our specification allows for nonlinear effects of household net income, financial and real wealth, and peers' net income (all of which have skewed distributions) by means of an inverse hyperbolic sine (IHS) transformation (i.e., $\log \left(x+\left(x^{2}+1\right)^{1 / 2}\right)$. The advantage of this near-logarithmic transformation is that it is defined for zero and negative values (see also Pence 2006). Our results are robust to alternative specifications of the aforementioned covariates (e.g., dummies denoting quartiles). 


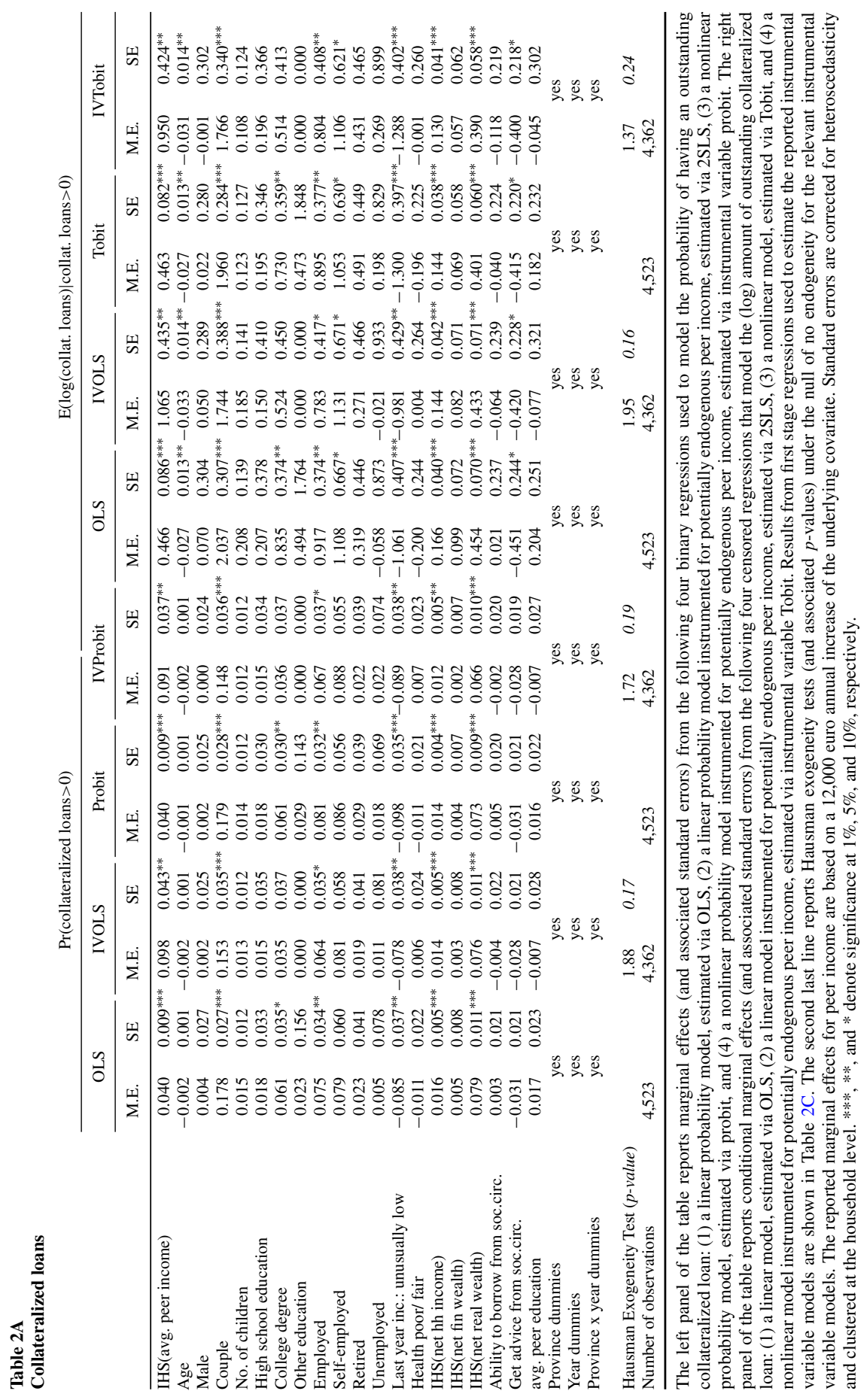


implying an almost $10 \%$ net contribution to the unconditional likelihood of having a mortgage. The estimated effects from the OLS and Tobit suggest a conditional elasticity of approximately 0.46 , corresponding roughly to a 15,000 euro increase in the amount borrowed by a typical household with collateralized debt. ${ }^{23}$ According to the Hausman tests (reported at the bottom of table), we fail to reject the null of peer income exogeneity, with $p$-values ranging from 0.19 to 0.24 . The results from all instrumented OLS, probit, and Tobit models yield estimates that are positive, almost double the size of the non instrumented ones, and statistically significant (with $p$-values less than 0.02).

Because our baseline specification allows for interactions between year and province fixed effects, it is flexible enough to account for any region-specific time trends that may influence individual borrowing decisions. Nonetheless, because the period under study is marked by a dramatic appreciation in housing prices and an increase in the home ownership rates relevant for collateralized debt, we perform additional tests on the robustness of our findings. Specifically, we estimate various specifications that control for year and province fixed effects, as well as for province-specific time trends of certain housing indicators. Table A4 reports results from the specifications with the province-specific yearly growth rates of housing prices, housing stock, and aggregate homeownership rates. We also estimate a specification with a quadratic time trend by province. In all cases, the results from both the probit and Tobit models are very similar to those derived under our baseline specification, which allows for any region-specific time trends by taking into account the interaction between province and time fixed effects.

Next, we test the sensitivity of our findings to the difference between collateralized borrowing for housing purchases and that for home equity extraction. Because our data do not allow for a direct distinction, we use the outstanding amount of the first mortgage on the main residence as a lowerbound estimate of the former. Our estimates of the marginal effects of peer income on the first mortgage on the main residence are very similar to those for total collateralized debt. ${ }^{24}$

Table $2 \mathrm{~B}$ reports the estimates related to uncollateralized consumer loans. We estimate a positive marginal effect of peer income on the probability of having consumer loans from both the OLS and probit models of the order of $1.6 \mathrm{pp}$ (i.e., contributing approximately $7 \%$ to the unconditional likelihood

23 This calculation is based on conditional medians of collateralized debt $(98,000$ euro) and of peers' income (34,500 euro) among households with outstanding collateral loans.

24 The conditional median (mean) outstanding amount of the first mortgage on the main residence is 83,194 euro $(102,921$ euro), with an average prevalence of $36 \%$. Hence, this first mortgage accounts for most of the collateralized borrowing over the period under study. The estimated marginal effect ( $p$-value) from probit on peer income is $4.1 \mathrm{pp}$ ( $p$-value is less than 0.001 ), whereas the corresponding estimated conditional elasticity from Tobit is 0.49 ( $p$-value is less than 0.001 ). 


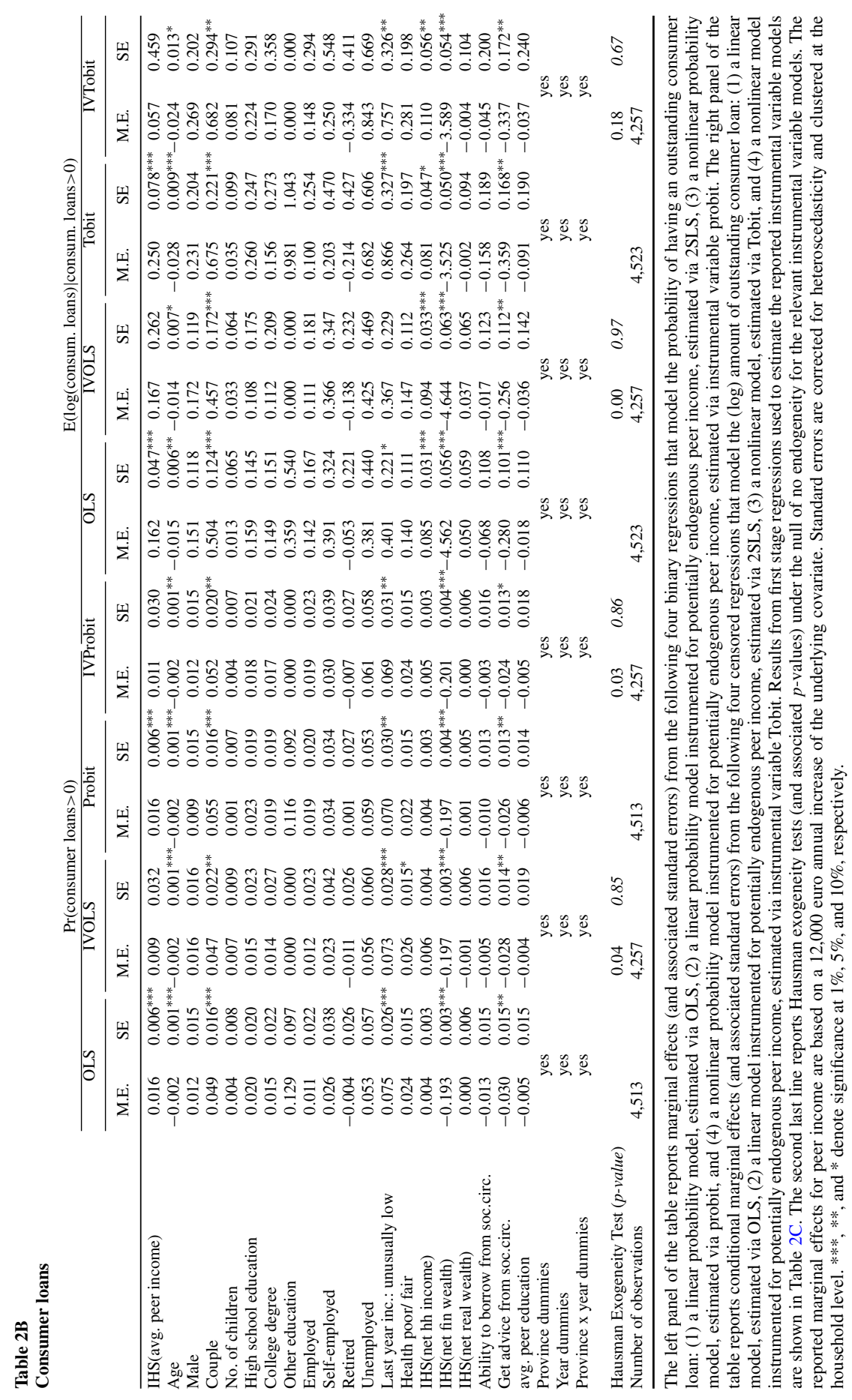


Table 2C

Auxiliary regressions

(I)

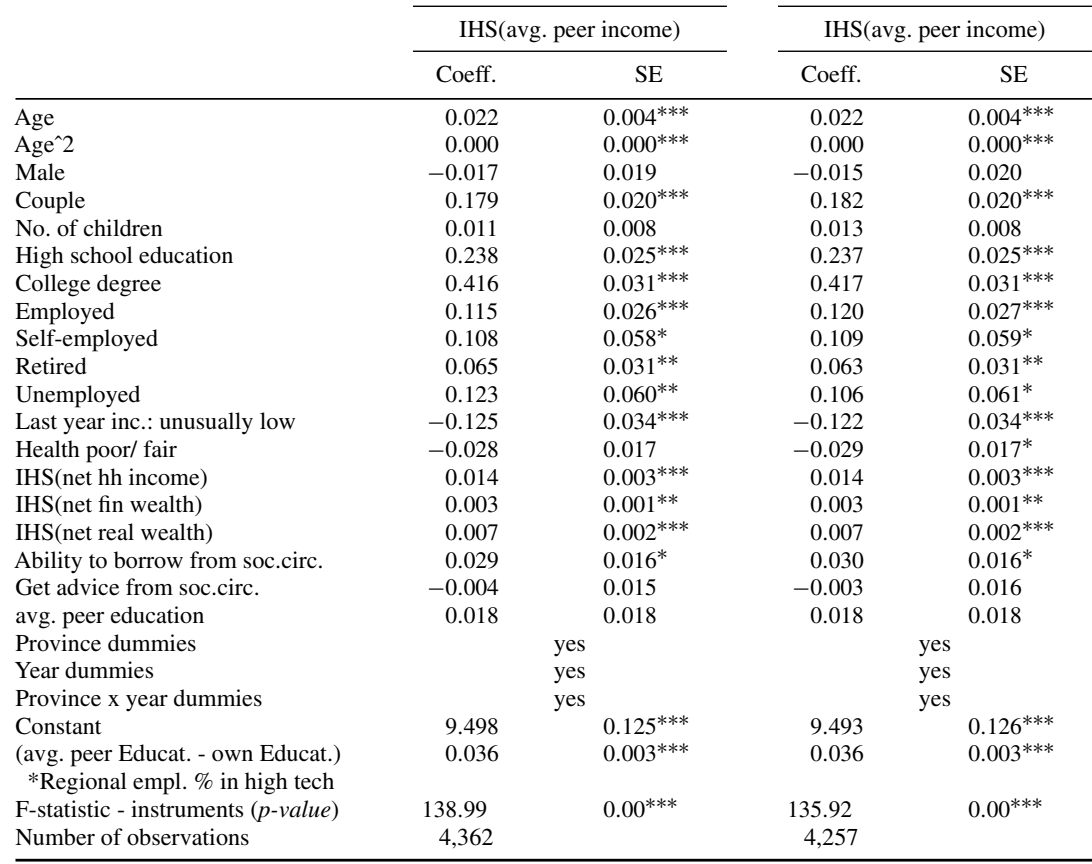

The table reports the firststage regressions (I) and (II) used to estimate instrumental variable models for collateralized (Table 2A) and consumer (Table 2B) loans, respectively. Standard errors are corrected for heteroscedasticity and clustered at the household level. ***,**, and $*$ denote significance at $1 \%, 5 \%$, and $10 \%$, respectively.

of having such loans). The corresponding elasticities of the size of consumer loans conditional on borrowing to peer income are of the order of 0.16 (OLS) to 0.24 (Tobit). The latter implies an increase of approximately 400 euro in the amount borrowed by a typical borrower. ${ }^{25}$ We fail to reject the null of peer income exogeneity in all OLS, probit, and Tobit models by a wide margin (with $p$-values ranging from 0.67 to 0.97 ). In view of this, our preferred estimates are those of the baseline models that are less biased compared with their IV counterparts (see Baum 2008).

\section{Placebo Tests and Additional Robustness Exercises}

To further investigate the issue of endogenous peer income, we perform a series of placebo tests to guard against the possibility of unobserved factors that influence both income and the borrowing choices of those of similar ages

25 Based on the conditional medians of uncollateralized debt (4,000 euro) and peers' income (26,000 euro) among households with consumer loans. 
and educations living in the same province. The underlying rationale is that if such factors were important, they would operate for any social circle sharing those characteristics and not only for the respondent's specific social circle. To conduct the placebo test, we construct cells based on respondents' age, education, province of residence, and interview year. Suppose that there are $g^{*}=1, \ldots, G^{*}$ such cells and $i=1, \ldots N_{g^{*}}$ households in each cell. For each household in a given cell, we then assign the perceived peer income of another randomly selected household in that same cell $\left(\hat{x}_{g^{*}}\right)$. We estimate the following specification:

$$
y_{i g}=\beta_{x} x_{i g}+\gamma_{\hat{x}} \hat{x}_{g^{*}}+Z_{1, i g}^{\prime} \beta+Z_{2, g}^{\prime} \gamma+\varepsilon_{i g} .
$$

The results from these placebo regressions are summarized in Table 3, Panels A1 and A2. Unlike the income of the respondents' actual social circle (i.e., $x_{g}$ in Equation 1), the randomly assigned income of acquaintances $\left(\hat{x}_{g^{*}}\right)$ is insignificant across all specifications (with $p$-values well above 0.40 and estimated magnitudes that are economically unimportant). We also perform additional placebo tests based on cells constructed using various combinations of the aforementioned traits and respondents' gender. In no cases do we find any significant effects for the (randomly assigned) incomes of acquaintances. These results further support the premise that the estimated effects of average peer income in our baseline specification reflect the effects of comparisons to peers, rather than being a relic of social group characteristics.

We next consider the possibility of unobserved factors that systematically influence both the propensity to borrow and the association with more affluent peers. If such factors exist, it would seem plausible that perceived peer income would have a stronger effect on borrowing among those who have received financial advice from friends and/or plan to borrow from friends in the future, two attributes directly recorded in the DNBHS data. We test for this possibility by introducing interaction terms into the baseline models between peer income and two dummies representing these attributes. In all the estimations, the two interaction terms are jointly statistically insignificant at $10 \%$.

Our third approach to assessing the potential relevance of unobserved factors for peer income is to take into account the entire set of peer characteristics asked about in the survey. To do so, we re-estimate the baseline models for loans (Equation 1), including the vector $Z_{2, g}$, which comprises peer characteristics other than income, namely, the average age, education, household size, and employment status of the social circle. In all cases, the estimated effects on peer income in terms of magnitude, sign, and significance remain unchanged, and the additional social circle characteristics prove mostly statistically insignificant (Table 3, Panels B1 and B2).

Lastly, we check the sensitivity of our findings to an income measure that is less volatile to temporary idiosyncratic shocks and local time trends than the current household income used in our baseline specifications. We follow Kapteyn, Alessie, and Lusardi (2005), who apply a standard life 
Table 3

Placebo regressions and robustness specifications

Panel A: I Placebo regressions: collateralized loans

\begin{tabular}{|c|c|c|c|c|}
\hline & \multicolumn{2}{|c|}{$\operatorname{Pr}($ collateralized loans $>0)$} & \multicolumn{2}{|c|}{$\mathrm{E}(\log ($ collat. loans $) \mid$ collat. loans $)>0$} \\
\hline & M.E. & SE & M.E. & SE \\
\hline IHS(avg. peer income) & 0.005 & 0.006 & 0.067 & 0.082 \\
\hline
\end{tabular}

Panel A: II Placebo regressions: consumer loans

\begin{tabular}{|c|c|c|c|c|}
\hline & \multicolumn{2}{|c|}{$\operatorname{Pr}($ consumer loans $>0)$} & \multicolumn{2}{|c|}{$\mathrm{E}(\log$ (cons. loans $) \mid$ cons. loans $)>0$} \\
\hline & M.E. & SE & M.E. & SE \\
\hline IHS(avg. peer income) & 0.000 & 0.005 & 0.007 & 0.055 \\
\hline
\end{tabular}

Panel B: I All peer characteristics: collateralized loans

\begin{tabular}{lcccc}
\hline & \multicolumn{2}{c}{$\operatorname{Pr}($ collateralized loans $>0)$} & & \multicolumn{2}{c}{ E(log(collat. loans) $\mid$ collat. loans) $>0$} \\
\cline { 2 - 3 } & M.E. & SE & M.E. & SE \\
\hline IHS(avg. peer income) & 0.041 & $0.008^{* * *}$ & 0.467 & $0.086^{* * *}$ \\
avg. peer education & 0.016 & 0.021 & 0.188 & 0.237 \\
avg. peer age & -0.002 & 0.002 & -0.023 & 0.128 \\
avg. peer household size & 0.004 & 0.011 & 0.046 & 0.487 \\
avg. peer self-employed & -0.016 & 0.045 & -0.166 & 0.389 \\
avg. peer employed & 0.002 & 0.032 & 0.066 & \\
\hline
\end{tabular}

Panel B: II All peer characteristics: consumer loans

\begin{tabular}{lrrrr}
\hline & \multicolumn{2}{c}{$\operatorname{Pr}($ consumer loans $>0)$} & & \multicolumn{2}{c}{ E $(\log$ (cons. $\operatorname{loans}) \mid$ cons. loans $)>0$} \\
\cline { 2 - 3 } & M.E. & SE & M.E. & SE \\
\hline IHS(avg. peer income) & 0.017 & $0.006^{* * *}$ & 0.264 & $0.082^{* * *}$ \\
avg. peer education & -0.007 & 0.014 & -0.133 & 0.197 \\
avg. peer age & 0.000 & 0.001 & -0.018 & 0.108 \\
avg. peer household size & -0.012 & 0.008 & -0.171 & $0.466^{*}$ \\
avg. peer self-employed & 0.049 & 0.032 & 0.850 & 0.292 \\
avg. peer employed & 0.024 & 0.020 & 0.415 & \\
\hline
\end{tabular}

Panel C: I Estimated permanent income: collateralized loans

\begin{tabular}{lccccc}
\hline & \multicolumn{2}{c}{$\operatorname{Pr}($ collateralized loans $>0)$} & & \multicolumn{2}{c}{ E $(\log$ (collat. loans) $\mid$ collat. loans $)>0$} \\
\cline { 2 - 3 } \cline { 5 - 6 } & M.E. & SE & & M.E. & SE \\
\hline IHS(avg. peer income) & 0.033 & $0.009^{* * *}$ & & 0.384 & $0.093^{* * *}$ \\
IHS(estimated permanent income) & 0.038 & $0.012^{* * *}$ & & 0.410 & $0.132^{* * *}$ \\
\hline
\end{tabular}

Panel C: II Estimated permanent income: consumer loans

\begin{tabular}{|c|c|c|c|c|}
\hline & \multicolumn{2}{|c|}{$\operatorname{Pr}($ consumer loans $>0)$} & \multicolumn{2}{|c|}{$\mathrm{E}(\log ($ cons. loans $) \mid$ cons. loans $)>0$} \\
\hline & M.E. & SE & M.E. & SE \\
\hline $\begin{array}{l}\text { IHS(avg. peer income) } \\
\text { IHS(estimated permanent income) }\end{array}$ & $\begin{array}{l}0.017 \\
0.007\end{array}$ & $\begin{array}{l}0.006^{* * *} \\
0.008\end{array}$ & $\begin{array}{l}0.268 \\
0.087\end{array}$ & $\begin{array}{l}0.090^{* * *} \\
0.099\end{array}$ \\
\hline
\end{tabular}

Panels A1 and A2 report marginal effects (and associated standard errors) of peer income for collateralized and consumer loans, respectively, derived from placebo probit and Tobit regressions. To that effect, each respondent in a given age, education, province, and interview year cell has been randomly assigned the peer income of another respondent in the same cell. Panels B1 and B2 report marginal effects (and associated standard errors) for collateralized and consumer loans, respectively, derived from probit and Tobit regressions that take into account the entire set of peer characteristics asked about in the survey (i.e., the average peer income, age, education, household size, and employment status of the social circle). Panels $\mathrm{C} 1$ and $\mathrm{C} 2$ report marginal effects (and associated standard errors) of the covariates of interest for collateralized and consumer loans, respectively, derived from probit and Tobit regressions in which current household own income has been replaced by an estimate of permanent household income (based on Kapteyn, Alessie, and Lusardi 2005). The marginal effects for peer income are based on a 12,000 euro annual increase of the underlying variable. All specifications in Panels A-C condition also on the set of covariates used in the baseline specifications in Tables $2 \mathrm{~A}$ and $2 \mathrm{~B}$. Standard errors are corrected for heteroscedasticity and clustered at the household level. ***, **, and * denote significance at $1 \%, 5 \%$, and $10 \%$, respectively. 
cycle permanent income hypothesis model to DNBHS data, ${ }^{26}$ and estimate a measure of permanent income for each household that represents the discounted present value of its future lifetime resources. More specifically, we regress noncapital income on an age spline, the interactions between age and education, gender, and family size, while controlling for household fixed effects, and then compute a measure of household permanent income by deriving predicted expected incomes at different ages for each household. ${ }^{27}$ We use this measure (instead of current household income, $x_{i g}$ ) to re-estimate Equation (1) for the two types of loans, but our results (Table 3, Panels $\mathrm{C} 1$ and $\mathrm{C} 2$ ) remain unaffected.

\section{Investigating the Nature of the Peer Income Effects}

It is plausible to suppose that the effects of perceived social circle income on loan behavior depend on whether the individual's own income is above or below that perceived level. In other words, we would expect that peer income more greatly affects those who perceive themselves as poorer than their peers than those who feel richer. We allow for such asymmetry by replacing peer income in our baseline models (Tables $2 \mathrm{~A}$ and $2 \mathrm{~B}$ ) with two terms denoting positive and negative differences between the respondent and peer income. Formally, we estimate the following specification:

$$
y_{i g}=\delta_{1} d_{i}\left(x_{i g}-x_{g}\right)+\delta_{2}\left(d_{i}-1\right)\left(x_{i g}-x_{g}\right)+Z_{1, i g}^{\prime} \beta+Z_{2, g}^{\prime} \gamma+\varepsilon_{i g},
$$

where $d_{i}$ takes value of one if $x_{i g}-x_{g} \geqslant 0$ and zero otherwise. ${ }^{28}$ Results from the nonlinear models for the two types of debt are reported in Table 4. For respondents who are poorer than they perceive their acquaintances to be, an assumed increase in their social circle's annual income of 12,000 euro (which raises the income gap relative to their peers) increases the probability of obtaining a collateralized loan by $3.5 \mathrm{pp}$ and a consumer loan by $1 \mathrm{pp}$. In fact, it is only the effects for those who perceive themselves as poorer than their social circle that are statistically significant, with respect to both participation and to conditional amounts.

Therefore, our results suggest that peer income and how it compares to the household's own income tend to influence borrowing. This tendency to obtain consumer loans and increase their size conditional on obtaining them is presumably motivated by a plan to boost consumer spending. The

26 We are grateful to Rob Alessie for providing the code to calculate the permanent household income.

27 Following Kapteyn, Alessie, and Lusardi (2005), we assume a constant interest rate of 3\% and a life expectancy of 80 years (which roughly corresponds to the average life expectancy in the Netherlands between 2000 and 2010).

28 In a linear regression model, the coefficient of the average perceived peers' income parameter, $\gamma_{x}$, is a weighted average of $-\delta_{1}$ and $\delta_{2}$. The relationship is more complicated for average marginal effects in the probit and Tobit models, which we report in Table 4, due to nonlinearities. 
Table 4

Asymmetric effects of peer income

Panel A: Collateralized loans

\begin{tabular}{ccccc}
\hline & \multicolumn{2}{c}{$\operatorname{Pr}($ collateralized loans $>0)$} & \multicolumn{2}{c}{$\mathrm{E}(\log ($ collat. loans $) \mid$ collat. loans $>0)$} \\
\cline { 2 - 5 } & M.E. & SE & M.E. & SE \\
\hline $\begin{array}{c}\text { IHS(own income)-IHS } \\
\text { (avg. peer income) }>0\end{array}$ & -0.006 & 0.006 & -0.030 & 0.065 \\
$\begin{array}{c}\text { IHS(own income)-IHS } \\
\text { (avg. peer income) }<0\end{array}$ & 0.035 & $0.005^{* * *}$ & 0.308 & $0.042^{* * *}$ \\
\hline
\end{tabular}

Panel B: Consumer loans

\begin{tabular}{ccccc}
\hline & \multicolumn{2}{c}{$\operatorname{Pr}($ consumer loans $>0)$} & \multicolumn{2}{c}{$\mathrm{E}(\log ($ cons. loans $) \mid$ cons. loans $>0)$} \\
\cline { 2 - 5 } & M.E. & SE & M.E. & SE \\
\hline $\begin{array}{c}\text { IHS(own income)-IHS } \\
\text { (avg. peer income) }>0\end{array}$ & 0.004 & 0.004 & 0.051 & 0.053 \\
$\begin{array}{c}\text { IHS(own income)-IHS } \\
\text { (avg. peer income) }<0\end{array}$ & 0.011 & $0.003^{* * *}$ & 0.175 & $0.050^{* * *}$ \\
\hline
\end{tabular}

Selected marginal effects (and associated standard errors) from probit and Tobit regressions for collateralized (Panel A) and consumer loans (Panel B). All specifications condition on the same set of covariates used in the baseline specifications in Tables $2 \mathrm{~A}$ and 2B, except from peer income that has been replaced by two indicators denoting positive and negative differences between respondent and peer income. The marginal effects of the relevant indicators are based on a 12,000 euro annual increase of peer income. Standard errors are corrected for heteroscedasticity and clustered at the household level. ***, **, and * denote significance at $1 \%, 5 \%$, and $10 \%$, respectively.

corresponding tendency for collateralized loans stems from efforts to acquire collateral assets of higher value. Thus, in what follows we take a closer look at the nature of the comparison income effect.

First, we look for evidence that at least part of the peer income effect can be attributed to a conspicuous consumption channel, for example, whether it comes from a comparison with peers' ability to spend on consumer goods. To this end, we use responses to a direct survey question on whether respondents see their acquaintances as having "more money to spend" than they do, coded on a seven-point ordinal scale from "strongly disagree" to "strongly agree." This reference to "money to spend" invites respondents to consider not only income but also the basic inelastic expenditure needs of their acquaintances (e.g., household size). For our part, this focus on others' spending ability allows assessment of whether the intensity of such a perception has an independent influence on consumer loans. To gain similar insights regarding collateralized loans, one would need to have direct information on respondents' perceptions of the social circle's housing and living arrangements. ${ }^{29}$ Unfortunately, our data do not provide such information.

In Table 5 (Panel A) we present results from our baseline specification for (uncollateralized) consumer loans, augmented by an ordinal variable denoting

29 Note that more than $90 \%$ of the outstanding collateralized debt of individuals with such debt is mortgages, with little variation over time. 


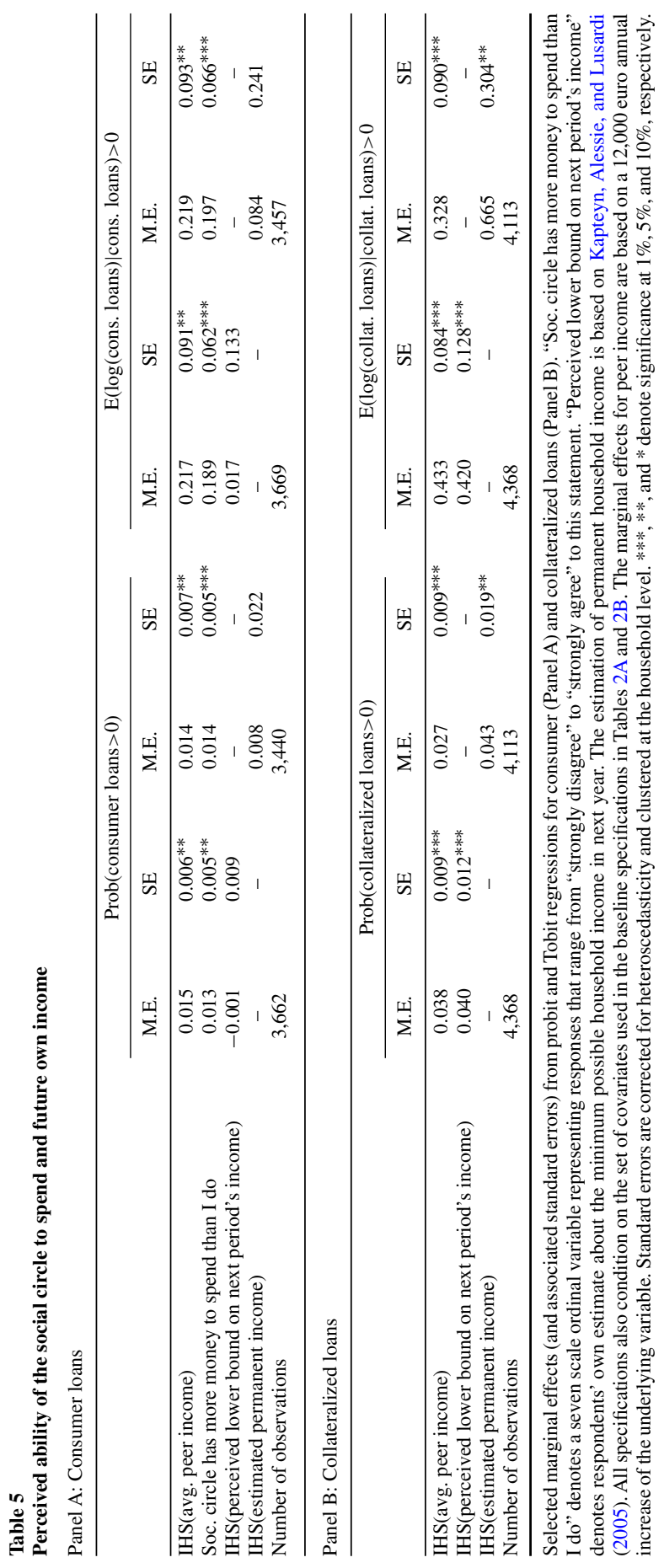

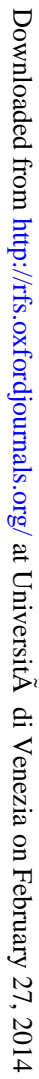


degree of agreement with the statement that "acquaintances have more money to spend" than does the respondent. Estimated marginal effects on this ordinal variable are positive and statistically significant for both participation and conditional amounts. Our results provide support to the hypothesis that a direct comparison with spending standards of peers partly influences the tendency of households to have uncollateralized loans, without making perceived peer income insignificant.

Probing further into the nature of the comparison effect of average peer income, we also examine whether part of the effect is linked to a "tunnel effect." The "tunnel effect" is likely to arise because higher peer incomes signal the potential for one's own higher income in the future. To this end, we consider two alternative measures. First, we take into account respondents' reported expectations about minimum possible incomes in the next year. Second, we control for a measure of permanent income that represents discounted lifetime resources. ${ }^{30}$ Both measures imply a positive and statistically significant effect in the specifications modeling collateralized debt (Table 5, Panel B), thereby supporting the presence of a "tunnel effect" for this type of loan. Nonetheless, the fact that including additional controls results in smaller, but still significant, marginal effects of perceived average peer income on borrowing suggests that the "tunnel effect" does not fully explain the influence of peer income. The remaining effects may well reflect alternative considerations that are not captured by the comparison effect proxy (included in the specification for consumer loans), such as envy or concerns about status.

Finding social effects on borrowing does not necessarily imply suboptimal or irrational behavior. Households may well borrow more because they have relative status concerns, but this does not necessarily mean that they do not plan to honor these debts. To examine the extent to which the perceived income of peers contributes to potential financial distress, we regress loan-to-value ratios and debt-service ratios on the perceived average income of peers and on the array of socioeconomic covariates used in our baseline specification (Equation 1). The Hausman exogeneity tests (not reported) show no evidence of endogenous peer income in either equation ( $p$-values $>0.4)$. The average marginal effects from the Tobit regressions, reported in Table 6, imply that an assumed 12,000 euro increase in the perceived annual income of peers contributes $1.2 \mathrm{pp}$ to an average loan-to-value ratio of $18 \%$ and $0.3 \mathrm{pp}$ to an average debt-service ratio of $6 \% .{ }^{31}$

These findings suggest that social comparisons contribute to the likelihood of households borrowing more and finding themselves in financial distress ex post,

\footnotetext{
30 The construction of the measure of permanent income is discussed in Section 4. Estimated marginal effects on permanent income refer to changes, net of current household income, which enters as an independent control in the specification.

31 Calculations are based on a median peer income of 33,000 euro.
} 
Table 6

Peer Income and overindebtedness

\begin{tabular}{|c|c|c|c|c|}
\hline & \multicolumn{2}{|c|}{$\mathrm{E}$ (loan to value ratio) } & \multicolumn{2}{|c|}{$\mathrm{E}$ (debt service ratio) } \\
\hline & M.E. & SE & M.E. & SE \\
\hline IHS(avg. peer income) & 0.0345 & $0.0059^{* * *}$ & 0.0095 & $0.0034^{* * *}$ \\
\hline Age & -0.0039 & $0.0008^{* * * *}$ & -0.0006 & 0.0005 \\
\hline Male & -0.0046 & 0.0161 & 0.0118 & 0.0109 \\
\hline Couple & 0.1156 & $0.0171^{* * *}$ & 0.0293 & $0.0107^{* * *}$ \\
\hline No. of children & 0.0102 & 0.0077 & 0.0005 & 0.0045 \\
\hline High school education & -0.0016 & 0.0189 & 0.0202 & $0.0116^{*}$ \\
\hline College degree & 0.0362 & $0.0211^{*}$ & 0.0326 & $0.0125^{* * *}$ \\
\hline Other education & 0.0708 & 0.1179 & 0.0510 & 0.0786 \\
\hline Employed & 0.0713 & $0.0208^{* * *}$ & 0.0345 & $0.0152^{* *}$ \\
\hline Self-employed & 0.0876 & $0.0394 * *$ & 0.0201 & 0.0230 \\
\hline Retired & 0.0466 & $0.0250^{*}$ & 0.0184 & 0.0164 \\
\hline Unemployed & 0.0178 & 0.0478 & 0.0285 & 0.0308 \\
\hline Last year inc.: unusually low & -0.0940 & $0.0224^{* * *}$ & -0.0495 & $0.0118^{* * *}$ \\
\hline Health poor/ fair & -0.0172 & 0.0138 & -0.0096 & 0.0089 \\
\hline IHS(net hh income) & 0.0107 & $0.0029^{* * *}$ & 0.0184 & $0.0017^{* * *}$ \\
\hline IHS(net fin wealth) & 0.0118 & $0.0049^{* *}$ & 0.0017 & 0.0025 \\
\hline IHS(net real wealth) & -0.0031 & 0.0072 & 0.0242 & $0.0042^{* * *}$ \\
\hline Ability to borrow from soc.circ. & -0.0129 & 0.0125 & -0.0043 & 0.0079 \\
\hline Get advice from soc.circ. & -0.0321 & $0.0135^{* *}$ & -0.0089 & 0.0083 \\
\hline avg. peer education & 0.0103 & 0.0132 & -0.0027 & 0.0086 \\
\hline Province dummies & \multicolumn{2}{|c|}{ yes } & \multicolumn{2}{|c|}{ yes } \\
\hline Year dummies & \multicolumn{2}{|c|}{ yes } & \multicolumn{2}{|c|}{ yes } \\
\hline Province $\mathrm{x}$ year dummies & \multicolumn{2}{|c|}{ yes } & \multicolumn{2}{|c|}{ yes } \\
\hline Number of observations & 4,504 & & 3,722 & \\
\hline
\end{tabular}

Marginal effects (and associated standard errors) from Tobit regressions used to model loan-to-value and debtservice ratios, as indicators of potential financial distress. The marginal effects for peer income are based on a 12,000 euro annual increase of the underlying variable. Standard errors are corrected for heteroscedasticity and clustered at the household level. ***,**, and * denote significance at $1 \%, 5 \%$, and $10 \%$, respectively.

but they do not necessarily imply that socially induced additional borrowing is irrational in the sense of violating the ex ante borrowing constraint at the time it is undertaken. Moreover, our findings on socially induced borrowing point to a demand-side factor affecting households with lower incomes than their peers, but normally lower incomes discourage financial institutions from extending a loan. Nevertheless, recent studies have found that, prior to the recent financial crisis, lenders relaxed their standards and were willing to let subprime or other less qualified borrowers carry substantial debt. ${ }^{32}$

\section{Concluding Remarks}

As discussed initially, although social influences can have notably distinct implications for consumption versus borrowing, the extant research tends to focus on identifying the social effects for the former. In this paper, we use unique information from the DNB's household survey, which is representative

32 Mian and Sufi (2009) show a shift in credit supply to be a key factor in the expansion of subprime mortgages in the United States; Demyanyk and Van Hemert (2012) find that the quality of such loans deteriorated for six consecutive years prior to the crisis; Christelis, Georgarakos, and Haliassos (2013) show that, prior to the crisis, older U.S. households had much higher mortgages than did European ones with similar characteristics and resources. 
of the entire Dutch population, to assess the effects of social interactions on the tendency to take on different types of debt, the size of loans conditional on obtaining them, and indicators of potential financial distress. Particularly, we exploit respondents' directly elicited perceptions of the average income in their social circle and the ability of their peers to spend, thereby circumventing the need to construct a hypothesized social circle based on arbitrary assumptions about its members' characteristics.

We find that the higher the perceived income of a social circle is, the greater the tendency is that respondents will have outstanding and sizeable loans. This finding holds true for both collateralized loans and uncollateralized consumer loans once such factors as household resources, reception of financial advice from the social circle, and belief in future borrowing from its members are controlled for. The effect is significant for those who see themselves as having lower income than their social circle.

We also find that once the perceived average income of the social circle is controlled for, the tendency of households to take out uncollateralized loans is partly related to the perceived spending ability of social circle members. Moreover, household expectations about the next period's (minimum) income are statistically significant for collateralized loans but do not render peers' perceived incomes insignificant. This finding suggests that average peer income does not simply reveal prospects for the future income of the respondent (a mere "tunnel effect") but also represents a comparison or envy effect. The role of comparison is also not confined to the tendency to borrow and the outstanding borrowing amount: it also extends to potential financial distress.

Overall, our study reveals a clear potential for social influences on household borrowing behavior. Particularly, those who perceive others as having higher average incomes not only try (as earlier studies show) to emulate their spending but also decide to borrow more. Although our analysis does not rule out that much of this socially induced additional borrowing is repayable, at least ex ante, our finding that it tends to worsen indicators of potential financial distress suggests that repayment problems might still occur ex post, especially if borrowers and lenders fail to take proper account of all relevant risk factors.

\section{Appendix A. Definitions of Variables and Summary Statistics}

\section{A.1. Types of debt}

Collateralized loans: Debts on hire-purchase contracts; debts based on payment by installment; equity based loans; debts with mail-order firms, shops or other retail business; mortgages on main house, second house and other pieces of real estate.

Consumer loans: Private loans; extended lines of credit (unrelated to home equity); study loans; credit card debts; other loans. 
Table A1

Summary statistics: Various demographics

\begin{tabular}{lccc} 
Variable & Average & SD & Number of observations \\
\hline Age & 48.23 & 15.41 & 14,893 \\
Male & 0.53 & 0.50 & 14,892 \\
Couple & 0.64 & 0.48 & 14,893 \\
Number of children & 0.64 & 1.03 & 14,893 \\
Education dummies: & & & \\
Less than high school & 0.27 & 0.44 & 14,815 \\
High school & 0.34 & 0.48 & 14,815 \\
College degree & 0.38 & 0.48 & 14,815 \\
Other education & 0.01 & 0.11 & 14,815 \\
Labour market status dummies: & & & \\
Unemployed & 0.02 & 0.14 & 14,889 \\
Employed & 0.54 & 0.50 & 14,889 \\
Self-employed & 0.04 & 0.20 & 14,889 \\
Retired & 0.17 & 0.37 & 14,889 \\
Other status & 0.23 & 0.42 & 11,342 \\
Last year income: unusually low & 0.07 & 0.25 & 11,791 \\
Health poor/fair & 0.28 & 0.45 & 8,782 \\
Ability to borrow from soc. circle & 0.28 & 0.45 & 11,454 \\
Get financial advice from friends & 0.34 & 0.47 & 8,939 \\
Soc. circle has more money to spend than I do & 3.85 & 1.47 & 13,081 \\
Loan-to-value ratio & 0.18 & 0.30 & 10,215 \\
Debt servicing ratio & 0.06 & 0.15 & \\
\hline
\end{tabular}

Weighted statistics from waves 2001-2008 of DNBHS data.

\section{A.2. Questions on characteristics of the social circle}

The following questions concern your circle of acquaintances, that is, the people with whom you associate frequently, such as friends, neighbors, acquaintances, or maybe people at work.

KENLTD. If you think of your circle of acquaintances, into which age category do MOST of these people go? Please select the answer that is closest to reality. Age (in years) is mostly: under 16; $16-20 ; 21-25 ; 26-30 ; 31-35 ; 36-40 ; 41-45 ; 46-50 ; 51-55 ; 56-60 ; 61-65 ; 66-70 ; 71$ or over.

KENHH. The people in your circle of acquaintances may live alone or share a household with other people (e.g., a partner and children). Of how many persons do MOST households of your acquaintances consist? One person; two persons; three persons; four persons; five persons; six persons or more.

KENINK. How much do you think is the AVERAGE total net income per year of those households? Less than $€ 8,000$ per year; $€ 8,000-9,500$; $€ 9,500-11,000$; $€ 11,000-13,000$; $€ 13,000$ 16,$000 ; € 16,000-20,000 ; € 20,000-28,000 ; € 28,000-38,000 ; € 38,000-50,000 ; € 50,000-75,000$; $€ 75,000$ or more; don't know.

KENOPL. Which level of education do MOST of your acquaintances have? Primary education; junior vocational training; lower secondary education; secondary education/preuniversity education; senior vocational training; vocational colleges/first year university education; university education.

KENWERK. Which kind of employment do MOST of your acquaintances have? Self-employed; practicing a free profession; working in the family business; employed on a contractual basis; mostly no paid job.

MANUUR (VROUWUUR). If you think of the MEN (WOMEN) among your acquaintances, how many hours per week do they work on average? 
Table A2

Summary statistics: Various economic indicators

\begin{tabular}{lcccccc} 
Variable & Mean & SD & 25th perc. & Median & 75th perc. & Number of obs. \\
\hline Avg. peer income & 31,807 & 13,955 & 24,000 & 33,000 & 36,941 & 6,872 \\
Net hh income & 27,617 & 23,638 & 15,943 & 24,687 & 35,886 & 10,031 \\
Net financial wealth & 36,137 & 100,092 & 1,393 & 10,847 & 36,430 & 11,412 \\
Net real wealth & 102,417 & 179,408 & 0 & 11,913 & 163,576 & 13,245 \\
Perceived lower bound on & 17,500 & 36,683 & 2,134 & 14,434 & 26,387 & 11,049 \\
next period's income & & & & & & \\
\hline
\end{tabular}

Weighted statistics from waves 2001-2008 of DNBHS data. Amounts refer to constant 2008 euro.

Table A3

Effects of peer income (taking into account “do not know" responses)

Panel A: Collateralized loans

\begin{tabular}{lllllc}
\hline & \multicolumn{2}{c}{$\operatorname{Pr}($ collateralized loans $>0)$} & & \multicolumn{2}{c}{ E(log(collat. loans) $\mid$ collat. $\operatorname{loans})>0$} \\
\cline { 2 - 3 } \cline { 5 - 6 } & M.E. & s.e. & & M.E. & s.e. \\
\hline IHS(avg. peer income) & 0.039 & $0.009^{* * *}$ & & 0.448 & $0.088^{* * *}$ \\
Number of observations & 6,373 & & & 6,373 & \\
\hline
\end{tabular}

Panel B: Consumer loans

\begin{tabular}{llllll}
\hline & \multicolumn{2}{c}{$\operatorname{Pr}($ consumer loans $>0)$} & & \multicolumn{2}{c}{$\mathrm{E}(\log ($ cons. loans $) \mid$ cons. $\operatorname{loans})>0$} \\
\cline { 2 - 3 } \cline { 5 - 6 } & M.E. & s.e. & & M.E. & s.e. \\
\hline IHS(avg. peer income) & 0.016 & $0.006^{* * *}$ & & 0.232 & $0.081^{* * *}$ \\
Number of observations & 6,373 & & & 6,373 & \\
\hline
\end{tabular}

Marginal effects (and associated standard errors) from probit and Tobit regressions for collateralized (Panel A) and consumer (Panel B) loans. All specifications condition on the same set of covariates used in the baseline specifications in Tables 2A and 2B and a "flag" dummy denoting households that answer "do not know" to the peer income question. The reported marginal effects for peer income are based on a 12,000 euro annual increase of the underlying covariate. Standard errors are corrected for heteroscedasticity and clustered at the household level. $* * * * *$, and $*$ denote significance at $1 \%, 5 \%$, and $10 \%$, respectively.

\section{A.3. Other questions}

Ability to borrow from social circle. Yes to "Are you currently in a position to borrow a substantial sum of money from family or friends?" (LENEN=1)

Get financial advice from friends. When answering "parents, friends, or acquaintances" to the following question: "What is your most important source of advice when you have to make important financial decisions for the household?" (ADVIES=1).

Social circle has more money to spend than I do. "Other people in my environment have more money to spend than I do. Please indicate to which extent you agree or disagree." (SITUAT3: 1: totally disagree ... 7: totally agree).

Last year income: unusually low. "Is the income your household earned in the past 12 months unusually high or low compared to the income you would expect in a 'regular' year, or is it regular?" (INKNORM=1: "Unusually low").

Perceived lower bound on next period's income. "What do you expect to be the LOWEST total net monthly income your household may realize in the next 12 months? (HOOG).

Province of residence. Data provide information on household location in twelve Dutch provinces: Groningen, Friesland, Drenthe, Overijssel, Flevoland, Gelderland, Utrecht, Noord-Holland, ZuidHolland, Zeeland, Noord-Brabant, and Limburg. 


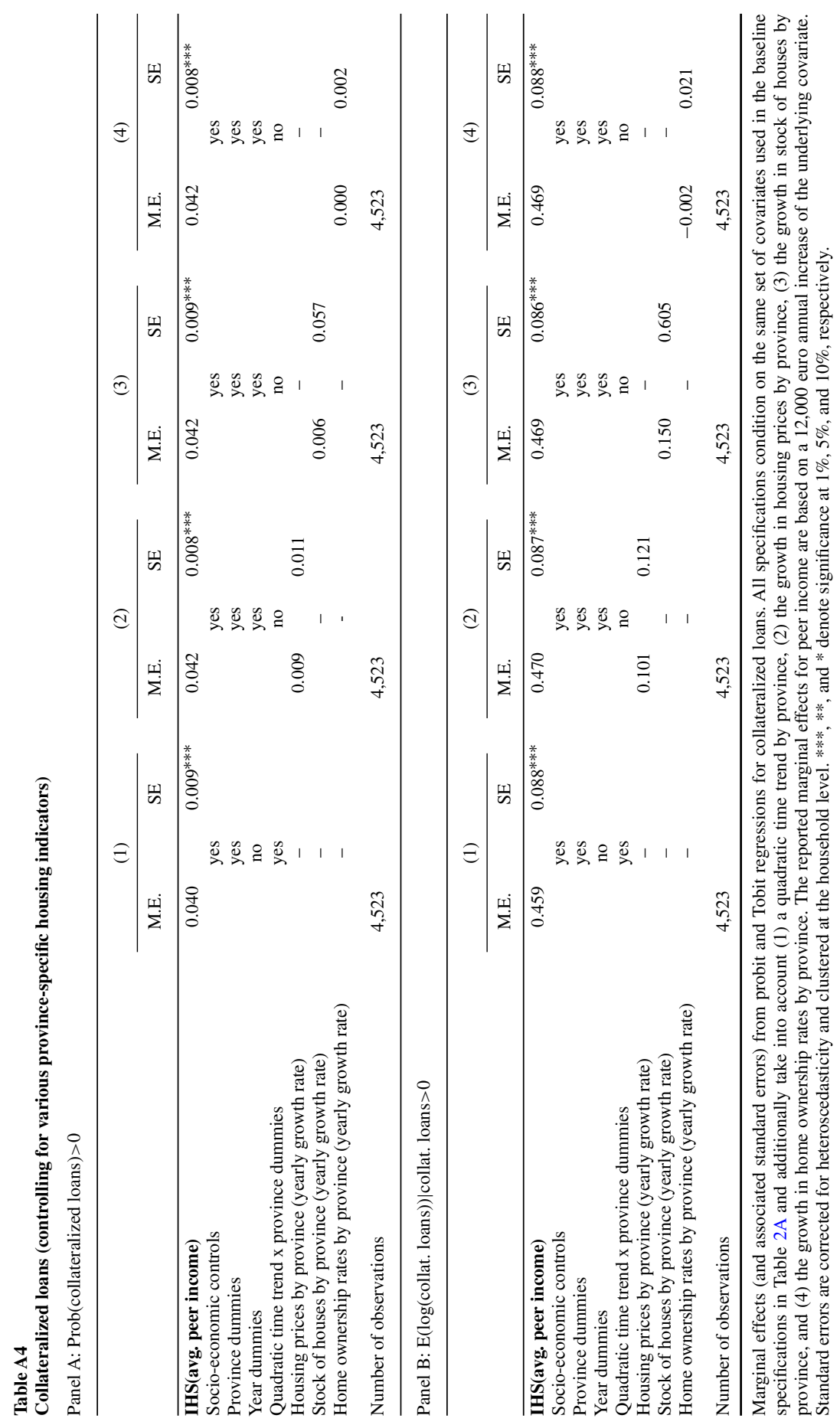

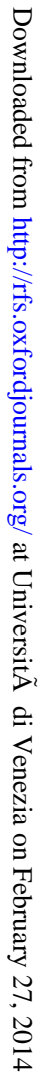




\section{Appendix B. Calculation of Average Marginal Effects via Monte Carlo Simulation}

Given that marginal effects are non-linear functions of the estimated parameters, $\hat{\beta}$ (either from probit or Tobit models), we compute their point estimates and standard errors via Monte Carlo simulation (Train 2003) using the following formula:

$$
E(g(\beta))=\int g(\beta) f(\beta) d \beta
$$

where $g(\beta)$ denotes the magnitude of interest and $f(\beta)$ denotes the joint distribution of all the elements in $\beta$. We implement this simulation estimator by drawing 500 times from the joint distribution of the estimated vector of parameters $\hat{\beta}$ under the assumption that it is asymptotically normal with the mean and variance-covariance matrix equal to the maximum likelihood estimates. Then, for a given parameter draw $j$, we generate the magnitude of interest $g\left(\hat{\beta}^{j}\right)$. We first calculate this magnitude for each household in our sample and then calculate the average marginal effect as the weighted average of the effect across all households in our sample using survey weights. ${ }^{33}$ We then estimate $E(g(\beta))$ and its standard error as the mean and standard deviation, respectively, of the distribution of $g\left(\hat{\beta}^{j}\right)$ over all parameter draws. Details on the formulae used to derive unconditional and conditional marginal effects after the Tobit estimation can be found in Greene (2000, Chapter 22).

In all tables the marginal effects for peer income are based on a 12,000 euro annual increase of the underlying variable. The marginal effect for age is derived from a second order age polynomial assuming a one year increase in age and the marginal effect for the number of children by assuming one additional child. The marginal effects for household income, financial wealth, real wealth, expected future income, and estimated permanent income are calculated assuming a one standard deviation increase of the underlying covariates.

\section{Appendix C. Induced Bias in the Case of Endogenous Peer Income}

Let $v_{i g}$ denote an unobserved factor that correlates both with own borrowing and the income of peers. In this case, model (1) can be rewritten as follows:

$$
y_{i g}=\beta_{x} x_{i g}+\gamma_{x} x_{g}+Z_{1, i g}^{\prime} \beta+Z_{2, g}^{\prime} \gamma+v_{i g}+\varepsilon_{i g} .
$$

Then, if $E\left(x_{g} v_{i g}\right) \neq 0$, the estimation of $\gamma_{x}$ will be biased. As is shown in Greene (2000), the sign of the bias can be easily determined only if the sign of $E\left(x_{g} v_{i g}\right)$ is known and $v_{i g}$ is uncorrelated with all other covariates in the model. However, this is quite unlikely to be the case in the context of social interactions. In particular, if the unobserved factor correlates with peer income, $x_{g}$, it also likely correlates with a household's own income (in which case $\left.E\left(x_{i g} v_{i g}\right) \neq 0\right)$. If we assume that $v_{i g}$ is uncorrelated with all the covariates in vectors $Z_{1, i g}$ and $Z_{2, g}$, the bias in the estimator of $\gamma_{x}$ would have the sign of the partial correlation of $x_{g}$ and $v_{i g}$ :

$$
\text { Bias }=\left[\operatorname{Cov}\left(x_{g} v_{i g}\right)-\operatorname{Cov}\left(x_{i g} v_{i g}\right)\right] / A,
$$

where A is a positive number. Even assuming further that both covariances in (C2) are positive, the sign of the bias is still undetermined.

Moffitt (2001) also considers the case of an average (across individuals within peers) unobserved peer characteristic (i.e., $v_{i g}=v_{g}$ ) and then shows that the covariance between peer-level variables $v_{g}$ and $x_{g}$ would be higher than the covariance between a group-specific indicator $\left(v_{g}\right)$ and an

33 We do not evaluate marginal effects at sample means because this practice can lead to severely misleading results (see Train 2003, 33-34). 
individual-level variable $\left(x_{i g}\right)$, thus inducing an upward bias in the estimator of $\gamma_{x}$. This is not necessarily the case in our set-up: each household reports the characteristics of its own peers; therefore, $x_{g}$ has the same support as $x_{i g}$, which implies that nothing can be said about the relative size of the two covariances even if the unobserved factor varies only by peer groups and not at the household level. As a result, it is not possible to predict the sign of the bias.

\section{Appendix D. Further Robustness Checks}

We performed a number of checks in addition to those presented in the main text to ensure the robustness of our findings. First, approximately $20 \%$ of the households answer "don't know" to the question regarding the perceived average income of their peers; thus, they are not used in our baseline regressions. To examine the sensitivity of our findings to the inclusion of these missing observations, we have re-estimated all our baseline models presented in Tables 2A and 2B and add a flag dummy to denote households answering that they do not know the income of their peers. For these observations, missing incomes of the peers are replaced by zeros. The estimated average marginal effects and associated standard errors for the income of peers from this larger sample of households are presented in Table A3. Notably, the estimated magnitudes across all specifications are very similar to those that we estimate in our baseline models.

Second, we experimented with different specifications that employ quartiles to model the income of peers, and our results are robust to such transformations. Our results are also insensitive to functional forms that use quartiles to model own income and/ or own financial and real wealth.

Third, our modeling strategy of borrowing behavior is quite standard in the household finance literature and in line with life-cycle portfolio models in which households decide every period on the allocation of their resources and the amount of borrowing. However, one may argue that for many households with collateralized loans outstanding in a given period, the decision to take up such loans (especially mortgages) was made many years prior to the interview. To examine the sensitivity of our results to this issue, we have re-estimated our probit model for collateralized loans, focusing only on households that take up such loans (i.e., switch borrowing status) during the period covered by our data. Specifically, we use the sample of households without collateralized loans in 2001 (i.e., the initial observation period in our sample) and estimate the probability of taking up such a loan in any of the subsequent seven waves. This probit model conditions on the same set of covariates as the one used in our baseline specification (presented in Table 2A). The estimated marginal effect on the income of the peers is $2 \mathrm{pp}$, significant at $1 \%$, and contributes almost $20 \%$ to the unconditional probability of taking up a collateralized loan in this sample. Thus, the estimated effects on the income of the peers from this 'inflow' sample are economically important and relatively stronger than those in our baseline specification.

Fourth, one might argue that the estimated effects of the income of peers on collateralized loans are partly due to expectations about future housing market conditions. To investigate this issue, we estimated specifications of collateralized debt behavior that take into account, apart from peers' income and expectations about next year's own income, various expectations regarding future conditions in housing and mortgage markets. These include whether respondents expect housing prices to go up, whether they anticipate an increase in mortgage interest rates, and whether they think that the tax deductibility of mortgage interest rates will be limited in the future. The results (available upon request) suggest a significant negative relationship between an expected increase in mortgage interest rates and collateralized debt, but they do not affect our baseline findings regarding the significant role of the income of peers or of expectations about next year's own income.

\section{References}

Abel, A. 1990. Asset prices under habit formation and catching up with the Joneses. American Economic Review $80: 38-42$.

Alvarez-Cuadrado, F., and N. Van Long. 2008. The relative income hypothesis. Working Paper, McGill University. 
Baum, C. 2008. Using instrumental variable techniques in economics and finance. Working Paper, Stata Users' Group meeting.

Blume, L. E., W. A. Brock, S. N. Durlauf, and R. Jayaraman. 2011. Linear social interactions models. Working Paper.

Brock, W., and S. N. Durlauf. 2001a. Discrete choice with social interactions. Review of Economic Studies 68:235-60.

2001b. Interactions-based models. In Handbook of econometrics, vol. 5. Eds. J. J. Heckman, and E. Leamer. Amsterdam: Elsevier Science.

- 2007. Identification of binary choice models with social interactions. Journal of Econometrics 140:52-75.

Brown, J., Z. Ivkovic, P. Smith, and S. Weisbenner. 2008. Neighbors matter: Causal community effects and stock market participation. Journal of Finance 63:1509-31.

Campbell, J., and J. Cochrane. 1999. By force of habit: A consumption-based explanation of aggregate stock market behavior. Journal of Political Economy 107:205-51.

Caplin, A., and J. Leahy. 2001. Psychological expected utility and anticipatory feelings. Quarterly Journal of Economics 116:55-80.

Charles, K., E. Hurst, and N. Roussanov. 2009. Conspicuous Consumption and Race. Quarterly Journal of Economics 124:425-67.

Christelis, D., D. Georgarakos, and M. Haliassos. 2013. Differences in portfolios across countries: Economic environment versus household characteristics. Review of Economics and Statistics 95:220-36.

Cohn, A., E. Fehr, B. Herrmann, and F. Schneider. 2011. Social comparison in the workplace: Evidence from a field experiment. IZA Discussion Paper No. 5550.

Collins, D., J. Morduch, S. Rutherford, and O. Ruthven. 2009. Portfolios of the poor: How the world's poor live on $\$ 2$ a day. Princeton, NJ: Princeton University Press.

Demyanyk, Y., and O. Van Hemert. 2012. Understanding the subprime mortgage crisis. Review of Financial Studies 24:1848-80.

Duesenberry, J. 1949. Income, saving and the theory of consumer behavior. Cambridge, MA: Harvard University Press

Duflo, E., and E. Saez. 2002. Participation and investment decisions in a retirement plan: The influence of colleagues'choices. Journal of Public Economics 85:121-48.

Durlauf, S. N., and Y. Ioannides. 2010. Social interactions. Annual Review of Economics 2:451-78.

Gali, J. 1994. Keeping up with the Joneses: Consumption externalities, portfolio choice, and asset prices. Journal of Money, Credit, and Banking 26:1-8.

Georgarakos, D., and G. Pasini. 2011. Trust, sociability, and stock market participation. Review of Finance 15:693-725.

Greene, W. 2000. Econometric analysis. New York: Macmillan.

Hirschman, A., and M. Rothschild. 1973. The changing tolerance for income inequality in the course of economic development. Quarterly Journal of Economics 87:544-66.

Hong, H., J. Kubik, and J. Stein. 2004. Social interaction and stock-market participation. Journal of Finance 59:137-63.

Kapteyn, A., R. Alessie, and A. Lusardi. 2005. Explaining the wealth holdings of different cohorts: Productivity growth and social security. European Economic Review 49:1361-91.

Kaustia, M., and S. Knüpfer. 2012. Peer performance and stock market entry. Journal of Financial Economics 104:321-38. 
Kuhn, P., P. Kooreman, A. Soetevent, and A. Kapteyn. 2011. The effects of lottery prizes on winners and their neighbors: Evidence from the Dutch Postcode Lottery. American Economic Review 101:2226-47.

Liu, W.-F., and S. Turnovsky. 2005. Consumption externalities, production externalities, and long-run macroeconomic efficiency. Journal of Public Economics 89:1097-129.

Lundborg, P. 2006. Having the wrong friends? Peer effects in adolescent substance use. Journal of Health Economics 25:214-33.

Manski, C. 1993. Identification of endogenous social effects: The reflection problem. Review of Economic Studies 60:531-42.

Mian, A., and A. Sufi. 2009. The consequences of mortgage credit expansion: Evidence from the U.S. mortgage default crisis. Quarterly Journal of Economics 124:1449-96.

Moffitt, R. A. 2001. Policy interventions, low-level equilibria, and social interactions. In Social dynamics, 45-82. Eds. S. N. Durlauf, and H. P. Young. Cambridge: MIT Press.

Neumark, D., and A. Postlewaite. 1998. Relative income concerns and the rise in married women's employment. Journal of Public Economics 70:157-83.

Pence, K. 2006. The role of wealth transformation: An application to estimating the effect of tax incentives on saving. Contributions to Economic Analysis and Policy 5:1-24.

Rivers, D., and Q. Vuong. 1988. Limited information estimators and exogeneity tests for simultaneous probit models. Journal of Econometrics 39:347-66.

Rayo, L., and G. Becker. 2006. Peer comparisons and consumer debt. University of Chicago Law Review 73:231-48.

Senik, C. 2004. When information dominates comparison: Learning from Russian subjective panel data. Journal of Public Economics 88:2099-133.

Soetevent, A. 2006. Empirics of the identification of social interactions: An evaluation of the approaches and their results. Journal of Economic Surveys 20:193-228.

Soetevent, A., and P. Kooreman. 2007. A discrete-choice model with social interaction with an application to high school teen behaviour. Journal of Applied Econometrics 22:599-624.

Train, K. 2003. Discrete choice methods with simulation. Cambridge: Cambridge University Press

Woittiez, I. and A. Kapteyn. 1998. Social interactions and habit formation in a model of female labour supply. Journal of Public Economics 70:185-205. 